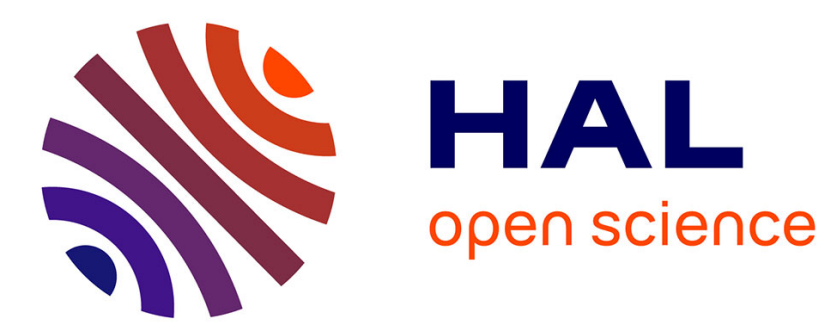

\title{
Butyric acid increases invasiveness of HL-60 leukemia cells: role of reactive oxygen species.
}

\author{
Doriane Richard, Patrick Hollender, Benoît Chénais
}

\section{To cite this version:}

Doriane Richard, Patrick Hollender, Benoît Chénais. Butyric acid increases invasiveness of HL-60 leukemia cells: role of reactive oxygen species.. FEBS Letters, 2002, 518 (1-3), pp.159-63. hal00422907

\section{HAL Id: hal-00422907 \\ https://hal.science/hal-00422907}

Submitted on 8 Oct 2009

HAL is a multi-disciplinary open access archive for the deposit and dissemination of scientific research documents, whether they are published or not. The documents may come from teaching and research institutions in France or abroad, or from public or private research centers.
L'archive ouverte pluridisciplinaire HAL, est destinée au dépôt et à la diffusion de documents scientifiques de niveau recherche, publiés ou non, émanant des établissements d'enseignement et de recherche français ou étrangers, des laboratoires publics ou privés. 


\title{
BUTYRIC ACID INCREASES INVASIVENESS OF HL-60 LEUKEMIA CELLS: ROLE OF REACTIVE OXYGEN SPECIES
}

Doriane Richard, Patrick Hollender and Benoît Chénais*

Unité MéDIAN, CNRS FRE-2141, Université de Reims-Champagne Ardenne, Faculté de Pharmacie, 51 rue Cognacq-Jay, F-51096 Reims cedex, France. Tel.: +33 326 918046, fax: +33 326 913550, e-mail: benoit.chenais@univ-reims.fr.

\begin{abstract}
Butyric acid (BA) induces differentiation of human leukemia, including HL-60 cells. By using a fluorescent probe, we showed that reactive oxygen species (ROS) were generated in BA-treated cells. BA-induced differentiation was accompanied with an increased secretion of pro-matrix metalloproteinase (MMP)-9. Both phenomena were inhibited by antioxidants. Tissue inhibitors of MMP (TIMP)-1 and -2 secretion was increased by BA, but differently affected by antioxidants. By contrast, BA did not affect MMP-9 mRNA, and decreased TIMP-1 and TIMP-2 mRNA levels. In addition, migratory and invasive properties of HL-60 cells were enhanced by BA, but differently affected by antioxidants. Altogether, these results indicate that ROS are messengers of BA-induced differentiation and increased invasiveness.
\end{abstract}

Keywords: butyrate, differentiation, invasion, leukemia, matrix metalloproteinase, oxidative stress.

*Corresponding author: Dr. Benoît Chénais, Unité MéDIAN, Faculté de Pharmacie, 51 rue Cognacq-Jay, F-51096 Reims cedex, France. Tel.: +33 326 918046, fax: +33 326 913550, email: benoit.chenais@univ-reims.fr. 
Abbreviations: AML-2, acute myeloid leukemia type 2; ATRA, all-trans-retinoic acid; BA, butyric acid; ELISA, enzyme-linked immunosorbent assay; MMP, matrix metalloproteinase; NAC, N-acetylcysteine; NBT, nitrobluetetrazolium; PDTC, pyrrolidine-dithiocarbamate; TIMP, tissue inhibitor of matrix metalloproteinase ; Vit E, $\alpha$-tocopherol.

\section{Introduction}

Differentiation of leukemia cells has prompted increasing research interest as an alternative or support to conventional cytotoxic chemotherapy $[1,2]$. In addition to the well documented effect of all-trans-retinoic acid (ATRA) [3, 4], butyric acid (BA) and derivatives appear as potential differentiating agents $[2,5]$. The differentiation effect of BA was clearly demonstrated in the human K562 cell line, which was then committed to the erythroid pathway $[6,7]$. The human leukemia cell line HL-60 represent a widely used model of acute myeloid leukemia type 2 (AML-2) [8], which can be committed toward granulocytic or monocytic pathways when exposed to ATRA or phorbol esters, respectively $[9,10]$. Differentiation of HL-60 cells can also be achieved with BA, even when discrimination among granulocytic or monocytic pathways is controversial [11]. Recently, several groups have shown that ATRA- or phorbol ester-induced differentiation of HL-60 cells is accompanied with changes in their matrix metalloproteinases (MMPs) expression [12-14].

MMPs are a family of zinc-dependent endopeptidases that degrade all of the components of extracellular matrix [15, 16]. MMP-2 and MMP-9 (gelatinases A and B), which are secreted as the latent forms proMMP-2 and proMMP-9, are the more frequently found in leukemia cells or cell lines [17]. MMPs expression, secretion and activity are highly regulated, particularly by a family of highly specific inhibitor proteins called tissue inhibitors of metalloproteinases (TIMPs) [18]. Therefore, secretion of MMP-9 and/or MMP-2 was thought 
to be involved in the invasive properties of malignant cells [19], including leukemia [20]. Nevertheless, biological significance of MMPs and TIMPs expression is complex since TIMPs could also have growth-promoting effects and numerous MMPs as well as other matrixdegrading enzymes could be involved in the invasive process [15-19].

In spite of the well known biological and clinical importance of BA, the molecular mechanisms leading to BA-induced cell growth regulation and differentiation, are poorly understood. Beside, inhibition of histone deacetylase, stimulation of protein phosphorylation, and the presence of butyrate responsive elements in BA-induced genes were thought to be responsible for some of the biological effects of BA [21-24]. We have previously shown the requirement of erythroid transcription factors NF-E2 and GATA-1 [7, 25] and the involvement of reactive oxygen species (ROS) [26] in the case of BA-triggered erythroid differentiation of K562 cells. Then we hypothesized that ROS would also be involved in the BA-triggered molecular and cellular events in HL-60 cells, including differentiation, MMP expression and invasiveness.

First we aimed at evaluating the effect of BA on MMP and TIMP expression, and invasiveness of HL-60 cells. Our second aim was to investigate the role of ROS in the differentiation induction, increased MMP-9 expression, and invasiveness by using antioxidant molecules.

\section{Materials and Methods}

\subsection{Chemicals}

Matrigel®, was purchased from BD Biosciences (Le Pont de Claix, France). The fluorescent probe 6-carboxy-2',7'-dichlorodihydrofluorescein diacetate, di(acetoxymethyl ester) (C2938) was from Molecular Probes (Eugene, Oregon). BA, $\alpha$-tocopherol (Vit E), Nacetylcysteine (NAC) and pyrrolidine dithiocarbamate (PDTC) were purchased from Sigma 
(L'Isle d'Abeau Chesnes, France), and were prepared as previously described [26], except NAC which was buffered to $\mathrm{pH} 7.4$ with sodium hydroxide.

\section{Cell culture}

The human leukemia HL-60 cell line from the American Type Culture Collection (CCL-240) was maintained in RPMI 1640 medium plus glutamax (Life Technologies, Saint Quentin en Yvelines, France) supplemented with 15\% heat-inactivated fetal calf serum (Life Technologies) under standard culture conditions. The presence of serum is required for differentiation induction in classical culture media but interferes with MMPs determination (gelatin zymography and immunoassays). Therefore, for all experiments, serum-free cultures of exponentially growing cells were performed in UltraCULTURE® medium (BioWhittaker, Emerainville, France) supplemented with $2 \mathrm{mM}$ L-glutamine, which allow both differentiation and MMP determination [27]. Cell number and viability were determined by the Trypan blue dye-exclusion method.

\section{Differentiation assay}

After 3 days of treatment with $0.5 \mathrm{mM} \mathrm{BA}$, and in the presence or absence of antioxidants, the differentiation of HL-60 cells was assessed by nitroblue tetrazolium (NBT) dye reduction as described previously [9, 27]. Cells containing blue-black formazan granules, indicative of the ability of HL-60 cells to generate superoxide anion during a phorbol esterinduced respiratory burst, were scored as differentiation positive. In addition, cytospin of control or BA-treated cells were stained with Wright-Giemsa [10, 27] and analysed by microscopy to allow the observation of granulocytic features (i.e. multilobular nucleus, prominent cellular indentation). 
Spectrofluorimetric determination of ROS

Cells $\left(1.10^{6} / \mathrm{ml}\right)$ were treated with $0.5 \mathrm{mM} \mathrm{BA}$ for $30 \mathrm{~min}$ to $6 \mathrm{~h}$, washed, then incubated with $5 \mu \mathrm{M}$ C2938 in RPMI-1640 without phenol red (Sigma) for 30 min at $37^{\circ} \mathrm{C}$ [28]. In some experiments PDTC $(1 \mu \mathrm{M})$ or Vit E $(50 \mu \mathrm{M})$ was added $1 \mathrm{~h}$ before and during BA treatment. After 3 washes, cells were resuspended in RPMI-1640 without phenol red and the fluorescence intensity was recorded between 505 and $600 \mathrm{~nm}$ with an excitation wavelength of $495 \mathrm{~nm}$. The maximal emission wavelength was $520 \mathrm{~nm}$.

Analysis of gene expression by RT-PCR

Total RNAs were extracted by using TRIZOL® reagent (Life Technologies) and $1 \mu \mathrm{g}$ was reverse transcribed by using the reverse transcription system from Promega (Charbonières, France). One tenth of the resultant cDNAs was then amplified with recombinant Taq-DNA polymerase (Life Technologies) as follow: $94^{\circ} \mathrm{C} / 90 \mathrm{sec}$; then $\mathrm{n}$ cycles consisting of $94^{\circ} \mathrm{C} / 30$ sec, $\mathrm{Tm} / 60 \mathrm{sec}$ and $72^{\circ} \mathrm{C} / 60 \mathrm{sec}$, and a final elongation step of $72^{\circ} \mathrm{C} / 10 \mathrm{~min}$. The primer sequences, Tm values, and number of PCR cycles used were: MMP-9, sense GCGGAGATTGGGAACCAGCTGTA, antisense GACGCGCCTGTGTACACCCACA, Tm $68^{\circ} \mathrm{C}, \quad \mathrm{n}=30 ; \quad$ TIMP-1, sense TCAGGCTATCTGGGACCGCAGGGA, antisense ACCATGGCCCCCTTTGAGCCCCTG, $\quad$ Tm $\quad 68^{\circ} \mathrm{C}, \quad \mathrm{n}=24 \quad$ [29]; $\quad$ TIMP-2, $\quad$ sense CGAGAAACTCCTGCTTGGGG, antisense CTCGGCAGTGTGTGGGGTC, $\mathrm{Tm} 68^{\circ} \mathrm{C}, \mathrm{n}=27$ [30]; GAPDH, sense CTCTGCCCCCTCTGCTGATGC, antisense CCATCACGCCACAGTTTCCCG, $\mathrm{Tm} 60^{\circ} \mathrm{C}, \mathrm{n}=23$. The PCR products were analyzed on a $1.4 \%$ agarose gel stained with ethidium bromide.

Gelatin zymography 
Gelatinolytic activities were analyzed as described previously [27]. Briefly, cell culture supernatants were harvested after 3 days of culture in UltraCULTURE medium in the presence or absence of $0.5 \mathrm{mM} \mathrm{BA}$ and/or antioxidants. Cellular extracts were then obtained after lysis in $0.1 \mathrm{M}$ Tris- $\mathrm{HCl} \mathrm{pH} 8.1,0.4 \%$ Triton $\mathrm{X}-100$. An appropriate volume of cell culture supernatant or cellular extract corresponding to an equal amount of cells (1-5 x $10^{3}$ cells) was applied to $10 \%$ SDS-polyacrylamide gels containing $1 \mathrm{mg} / \mathrm{mL}$ gelatin. After migration, SDS was removed by two incubations in $2 \%$ Triton X-100 during 30 minutes, then gelatinases were activated by overnight incubation at $37^{\circ} \mathrm{C}$ in $50 \mathrm{mM}$ Tris- $\mathrm{HCl} \mathrm{pH} 7.4,0.2 \mathrm{M} \mathrm{NaCl}$ and $5 \mathrm{mM}$ $\mathrm{CaCl}_{2}$. Proteolytic activities were evidenced as clear bands against the blue background of the Coomassie blue-stained gelatin.

\section{Invasion and migration assay}

In vitro invasion was determined in the Matrigel@-based assay as described previously by Janiack et al [31]. Briefly, 13-mm polycarbonate filters of $8-\mu \mathrm{m}$ pore size (Costar, Cambridge, MA) were coated with $50 \mu \mathrm{g}$ Matrigel. The lower compartments of the transwell chambers were filled with serum-free UltraCULTURE® medium. Following indicated treatment, cells suspended in UltraCULTURE® medium were placed in the upper compartment ( $4 \times 10^{5}$ cells/chamber) and incubated for $6 \mathrm{~h}$ at $37^{\circ} \mathrm{C}$, in $5 \% \mathrm{CO}_{2}$. After incubation, cells that had migrated through the Matrigel@-coated filters were recovered from the lower compartments and counted. The percentage of invasion was calculated by considering the number of cells in the initial cell suspension as $100 \%$. To study cell migration, filters were not coated with Matrigel ${ }^{\circledR}$ and subsequent procedure was the same as for the invasion assay. Each experiment was performed in triplicate for each sample. 
Following indicated treatment, the MMP-9, TIMP-1 and TIMP-2 proteins levels were quantified by ELISA (Biotrak ${ }^{\mathrm{TM}}$, Amersham-Biosciences, Orsay, France) in conditioned media from $10^{5}$ cells, according to the manufacturer's instructions.

\section{Statistics}

Results from at least three independent experiments were given as mean $\pm \mathrm{SD}$, and oneway ANOVA with Student-Newman-Keuls post-hoc comparison was used for statistical significance with $\mathrm{p} \leq 0.01$.

\section{Results and discussion}

\subsection{ROS production in BA-treated cells}

In order to show ROS production, cells were treated with $0.5 \mathrm{mM} \mathrm{BA}$ for periods of time varying from $30 \mathrm{~min}$ to $6 \mathrm{~h}$, then incubated with the carboxyfluoresceine derivative C2938, the intracellular fluorescence of which is enhanced in the presence of ROS [28]. For each time point, the $520 \mathrm{~nm}$ fluorescence level was measured in control and BA-treated cells. The ratio obviously indicate a ROS production in BA-treated HL-60 cells, which was maximal for a $3 \mathrm{~h}$ treatment and then declined (Fig. 1). In addition, the co-treatment of cells with BA and either PDTC $(1 \mu \mathrm{M})$ or Vit $\mathrm{E}(50 \mu \mathrm{M})$ antioxidant, inhibited the BA-induced ROS production (Fig. 1) indicating that the fluorescence augmentation was related to ROS production. According to the literature, the antioxidant NAC has been avoided as it interfered with the fluorescence determination [28]. 


\subsection{Inhibition of BA-induced differentiation by antioxidants}

An average of $75 \%$ of cells were induced to differentiate after 3 days of treatment with $0.5 \mathrm{mM}$ of BA (Fig. 2). The cytological observation of BA-treated cells after Wright-Giemsa coloration confirmed the granulocytic differentiation of HL-60 cells (not shown). This differentiation was accompanied with a marked inhibition of cell growth (59\%) but no cytotoxicity ( $>95 \%$ of viable cells). As shown in Fig. 2, the BA-induced differentiation of HL60 cells was strongly inhibited by antioxidants. NAC $(5 \mathrm{mM})$, PDTC $(1 \mu \mathrm{M})$ and Vit E (50 $\mu \mathrm{M})$, which have no significant effect on control cells, diminished BA-induced differentiation to an average of $17 \%$ after 3 days of co-treatment (Fig. 2). It is important to notice that antioxidants increased the cell growth inhibition to an average of $70 \%$ and that higher concentration of these compounds became cytotoxic to HL-60 cells. These data confirmed that ROS are mediators of the BA-induced differentiation process in HL-60 cells, as previously suggested in the erythroid K562 model [26].

\subsection{MMP-9 expression was increased by BA and inhibited by antioxidants}

Untreated HL-60 cells have been previously described to express mainly MMP-9 gelatinase activity [17]. Gelatin zymography analysis of cell culture supernatants indicated that proMMP-9 secretion was strongly increased by BA treatment and inhibited in the presence of either NAC, PDTC or Vit E (Fig. 3A). It should be noticed that, both PDTC and Vit E alone increased the proMMP-9 secretion in control cells. This can explain the lower inhibition of BA-enhanced proMMP-9 secretion observed with PDTC or Vit E by contrast with NAC effect (Fig. 3A). The ROS-mediated increase of proMMP-9 in BA-treated cells was confirmed by the quantification of proMMP-9 in cell culture supernatants by ELISA assay (Table 1). At the mRNA level, MMP-9 gene expression remained unchanged after BA-treatment, and antioxidants were without significant effect (Fig. 3B). Altogether, these results support the role 
of ROS as mediators of BA-induced increase of proMMP-9 secretion, but ruled out a transcriptional effect of BA.

3.4 TIMP-1 and TIMP-2 secretion was increased by BA, but differently sensitive to antioxidants

TIMPs are the physiological inhibitors of MMPs activity and their expression and/or secretion is thought to be coordinated with MMP control. TIMP-1 and TIMP-2 levels were therefore determined by ELISA assay in cell culture supernatants. Results indicated that TIMP-1 secretion was markedly increased in BA-treated cells with respect to control cells and decreased in the presence of the antioxidant NAC or PDTC together with BA (Table 2). By contrast, TIMP-2 level was increased in a lesser extent and in a ROS-independent way (Table 2). Surprisingly, RT-PCR analysis showed that TIMP-1 and TIMP-2 mRNA steady-state levels were decreased in BA-treated cells (Fig. 3B). The TIMP-2 mRNA level was insensitive to the presence of antioxidant in both control and BA-treated cells. By contrast, the BA-induced decreased of TIMP-1 mRNA level was inhibited by PDTC, and, in a lower extent by NAC (Fig. 3B). Altogether, these results suggest the involvement of a complex regulation of TIMP1 and TIMP-2 by BA, combining transcriptional down-regulation and post-transcriptional stimulation, and both ROS-dependent and independent events.

\subsection{Cell migration and invasiveness were increased by BA treatment}

The above results suggest that BA is a modulator of the migration and/or invasiveness capacity of HL-60 cells. We used transwell filters recovered, or not, by a Matrigel® layer to evaluate cell invasiveness or migration, respectively. As shown in Fig. 4A, an average of 3\% of control HL-60 cells were able to cross the Matrigel ${ }^{\circledR}$ layer and the filter, this percentage was increased to $21 \%$ for BA-treated cells. The co-treatment with BA and antioxidant reduced the 
percentage of invasive cells to an average of $14 \%$ and $9 \%$ with NAC or Vit E, respectively ( $\mathrm{p}<0.01$, Fig. 4A). This supports the involvement of MMP-9, the secretion of which was ROSdependent. Furthermore, cell migration (i.e. in the absence of Matrigel ${ }^{\circledR}$ ), which is independent of matrix degrading enzymes, was increased by BA treatment, but was unaffected in the presence of NAC or Vit E (Fig. 5B).

\subsection{Conclusions}

Our results show for the first time that BA-induced differentiation was accompanied with an increase of the migratory and invasive properties of HL-60 cells. Particularly, the extracellular secretion of proMMP-9, TIMP-1 and TIMP-2 was found increased in BA-treated HL-60 leukemia cells as previously observed in the colon cancer cell line SW1116 [32]. However, these authors show that cell invasiveness was inhibited in BA-treated SW1116 cells [32]. This suggest that the BA effect is cell type-dependent, maybe according to the invasive potential of the untreated cells, which was very low for HL-60 cells (3\%). Nevertheless, our results could not be attributed to the classical transcriptional up-regulation often seen with BA and mediated by histone deaceatylase inhibition [21], since mRNA levels for MMP-9 and TIMPs were found unchanged or down-regulated, respectively. Beside, we have showed that BA induce ROS production in the first hours of treatment. Then, ROS were obviously involved in the BA-induced differentiation and proMMP-9 secretion, and, at least in part, in the increased invasiveness of BA-treated HL-60 cells. By contrast, the inhibition of ROS synthesis by antioxidants did not significantly affect the BA-enhanced migration of HL-60 cells suggesting the stimulation of other signaling pathways.

Acknowledgements: This work was supported by a joint grant from ARERS and the Ligue Nationale contre le Cancer, Comité de l'Aisne. 


\section{REFERENCES}

[1] Beere, H.M. and Hickman, J.A. (1993) Anti-cancer Drug Design 8, 299-322.

[2] Waxman, S. (2000) Leukemia 14, 491-496.

[3] Fenaux, P., Chomienne, C. and Degos, L. (2001) Semin. Hematol. 38, 13-25.

[4] Zhang, J.W., Wang, J.Y., Chen, S.J. and Chen, Z. (2000) J. Biosci. 25, 275-284.

[5] Newmark, H.L. and Young, C.W. (1995) J. Cell. Biochem. Suppl. 22, 247-253.

[6] Anderson, L.C., Jokinen, M. and Gahmberg, C.G. (1979) Nature 278, 364-365.

[7] Chénais, B., Molle, I., Trentesaux, C. and Jeannesson, P. (1997) Leukemia 11, 15751579.

[8] Dalton, W.T., Ahearn, M.J., McCredie, K.B., Freireich, E.J., Strass, S.A. and Trujillo, J.M. (1988) Blood 71, 242-247.

[9] Breitman, T.R., Selonick, S.E. and Collins, S.J. (1980) Proc. Acad. Sci. USA 77, 29362940.

[10] Perkins, S.L. and Yunis, A.A. (1986) Exp. Hematol. 14, 401-405.

[11] Hoessly M.C., Rossi R.M. and Fischkoff S.A. (1989) Cancer Res. 49, 3594-3597.

[12] Devy, L., Noël, A., Baramova, E., Bajou, K., Trentesaux, C., Jardillier, J.C., Foidart, J.M. and Jeannesson, P. (1997) Biochem. Biophys. Res. Commun. 238, 842-846.

[13] Ries, C., Lottspeich, F., Dittmann, K.H. and Petrides, P.E. (1996) Leukemia 10, 15201526.

[14] Davis, G.E. and Martin, B.M. (1990) Cancer Res. 50, 1113-1120.

[15] Vincenti, M.P. (2001) Methods Mol. Biol. 151, 121-148.

[16] Nagase, H. and Woessner, J.F. Jr. (1999) J. Biol. Chem. 274, 21491-21494. 
[17] Janowska-Wieczorek, A., Marquez, L.A., Matsuzaki, A., Hashmi, H.R., Larratt, L.M., Boshkov, L.M., Turner, A.R., Zhang, M.C. and Edwards, D.R. (1999) Br. J. Haematol. $105,402-411$.

[18] Brew, K., Dinakarpandian, D. and Nagase, H. (2000) Biochim. Biophys. Acta. 1477, 267-283.

[19] Westermarck, J. and Kahari, V.M. (1999) FASEB J. 13, 781-792.

[20] Sawicki, G., Matsuzaki, A. and Janowska-Wieczorek, A. J. (1998) Cancer Res. Clin. Oncol. 124, 245-52.

[21] Kruh, (1982) J. Mol. Cell. Biol. 42, 65-82.

[22] Pace, B.S., Li, Q. and Stamatoyannopoulos, G. (1996) Blood 88, 1079-1083.

[23] Rivero, J.A. and Adunyah, S.E. (1998) Biochem. Biophys. Res. Commun. 248, 664-668.

[24] Rivero, J.A. and Adunyah, S.E. (1996) Biochem. Biophys. Res. Commun. 224, 796-801.

[25] Chénais, B. (1998) Biochem. Biophys. Res. Commun. 253, 883-886.

[26] Chénais, B., Andriollo, M., Guiraud, P., Belhoussine, R. and Jeannesson, P. (2000) Free Radic. Biol. Med. 28, 18-27.

[27] Devy, L., Hollender, P., Munaut, C., Colige, A., Garnotel, R., Foidart, J.-M., Noël, A. and Jeannesson, P. (2002) Biochem. Pharmacol. 63, 179-189.

[28] Mansat-de Mas, V., Bezombes, C., Quillet-Mary, A., Bettaieb, A., D'orgeix, A.D., Laurent, G. and Jaffrezou, J.P. (1999) Mol. Pharmacol. 56, 867-874.

[29] Stetler-Stevenson, M., Mansoor, A., Lim, M., Fukushima, P., Kehrl, J., Marti, G., Ptaszynski, K., Wang, J. and Stetler-Stevenson, W.G. (1997) Blood 89, 1708-1715.

[30] Brassart, B., Randoux, A., Hornebeck, W. and Emonard, H. (1998) Clin. Exp. Metastasis 16, 489-500.

[31] Janiak, M., Hashmi, H.R., and Janowska-Wieczoreck, A. (1994) Exp. Hematol. 22, 559565. 
[32] Emenacker, N.J. and Basson, M.D. J. (1998) Surg. Res. 76, 41-46. 
Table 1. Determination of proMMP-9 level in HL-60 cell cultures.

\begin{tabular}{ccc}
\hline Antioxidant & \multicolumn{2}{c}{ Level of proMMP-9 $\left(\mathrm{ng} / 10^{5} \text { cells }\right)^{\mathrm{a}}$} \\
treatment & & \\
\cline { 2 - 3 } & Control & BA \\
\hline None & $0.92 \pm 0.52^{\mathrm{b}}$ & $6.51 \pm 2.48^{\mathrm{c}}$ \\
NAC & $0.49 \pm 0.39$ & $1,36 \pm 0.59^{\mathrm{d}}$ \\
PDTC & $1.64 \pm 0.66$ & $4.29 \pm 0.46^{\mathrm{d}}$
\end{tabular}

${ }^{\mathrm{a}}$ The level of proMMP-9 secretion was determined by ELISA in 3 days culture supernatants of control and BA-treated HL-60 cells in the presence or absence of antioxidant (NAC, $5 \mathrm{mM}$;

PDTC, $1 \mu \mathrm{M}) .{ }^{\mathrm{b}}$ Data are the mean \pm SD of three independent experiments, each done in triplicate. ${ }^{\mathrm{c}}$ Value significantly different from the control according to one-way ANOVA with Student-Newman-Keuls post-hoc comparison $(\mathrm{p}<0.01) .{ }^{\mathrm{d}}$ Value significantly different from BA $(\mathrm{p}<0.01)$ 
Table 2 TIMP-1 and TIMP-2 levels in HL-60 cell cultures.

\begin{tabular}{ccc}
\hline treatment & TIMP-1 & TIMP-2 \\
& $\left(\mathrm{ng} / 10^{5}\right.$ cells $^{\mathrm{a}}$ & $\left(\mathrm{ng} / 10^{5} \text { cells }\right)^{\mathrm{a}}$ \\
\hline Control & $4.07 \pm 0.98^{\mathrm{b}}$ & $2.33 \pm 0.87$ \\
NAC & $2.02 \pm 0.92$ & $2.17 \pm 0.27$ \\
BA & $44.39 \pm 4.53^{\mathrm{c}}$ & $4.51 \pm 0.31^{\mathrm{c}}$ \\
BA + NAC & $11.47 \pm 5.31^{\mathrm{c}, \mathrm{d}}$ & $4.05 \pm 0.38^{\mathrm{c}}$
\end{tabular}

${ }^{\mathrm{a}}$ The levels of TIMP-1 and TIMP-2 were determined by ELISA in 3 days culture supernatants of control and BA-treated HL-60 cells in the presence or absence of NAC (5 mM). ${ }^{\mathrm{b}}$ Data are the mean \pm SD of three independent experiments, each done in triplicate. ${ }^{c}$ Value significantly different from the control according to one-way ANOVA with Student-Newman-Keuls posthoc comparison $(\mathrm{p}<0.01) .{ }^{\mathrm{d}}$ Value significantly different from BA $(\mathrm{p}<0.01)$. 


\section{FIGURE LEGENDS}

Fig. 1. ROS production in BA-treated cells. HL-60 cells were treated, or not, for the indicated time with $0.5 \mathrm{mM}$ BA in the presence, or absence, of PDTC $(1 \mu \mathrm{M})$ or Vit $\mathrm{E}(50 \mu \mathrm{M})$ before incubation with $5 \mu \mathrm{M}$ of $\mathrm{C} 2938$ probe for 30 minutes. For each time point, the fluorescence intensity was recorded by spectrofluorimetry $\left(\lambda_{\mathrm{ex}}, 495 \mathrm{~nm} ; \lambda_{\mathrm{em}}, 520 \mathrm{~nm}\right)$ and results were expressed as the relative fluorescence intensity (\%) with respect to untreated cells. Results are the mean of three independent experiments and SD were comprised between 10 and $20 \%$ of the value.

Fig. 2. Inhibition of BA-induced differentiation by antioxidants. HL-60 cells were treated, or not (Control), for 3 days with $0.5 \mathrm{nM} \mathrm{BA}$ in the presence, or absence, of either $5 \mathrm{mM}$ NAC, $1 \mu \mathrm{M}$ PDTC, or $50 \mu \mathrm{M}$ Vit E. The percentage of differentiation was assessed by the NBT test. Data are the mean \pm SD of five independent experiments. Statistical significance was tested with one-way ANOVA with post-hoc Student-Newman-Keuls comparison; columns with different letters significantly differ from each other $(\mathrm{p}<0.01)$.

Fig. 3. BA increases (pro)MMP-9 secretion but not MMP-9 and TIMPs mRNA levels. HL-60 cells were treated, or not (Control) for 3 days with $0.5 \mathrm{mM} \mathrm{BA}$ in the presence, or absence, of $5 \mathrm{mM}$ NAC or $1 \mu \mathrm{M}$ PDTC. Then culture media were harvested and total RNA extracted (A) Analysis of proMMP-9 secretion by gelatin zymography of culture media. (B) RT-PCR analysis of MMP-9, TIMP-1 and TIMP-2 expression following indicated treatments. Results from one experiment representative of three. 
Fig. 4. BA increases HL-60 cells invasion and migration. HL-60 cells were treated, or not (Control) for 3 days with $0.5 \mathrm{mM} \mathrm{BA}$ in the presence, or absence, of $5 \mathrm{mM} \mathrm{NAC}$ or $50 \mu \mathrm{M}$ Vit E. (A) The $\%$ of invasive cells was determined as the $\%$ of cells which have crossed the Matrigel®-coated filter after a $6 \mathrm{~h}$ incubation period. (B) The $\%$ of migrating cells was determined as previously with uncoated filters. Results are the mean \pm SD of three independent experiments, each done in triplicate. Statistical significance was tested with one-way ANOVA with post-hoc Student-Newman-Keuls comparison; columns with different letters significantly differ from each other $(\mathrm{p}<0.01)$. 


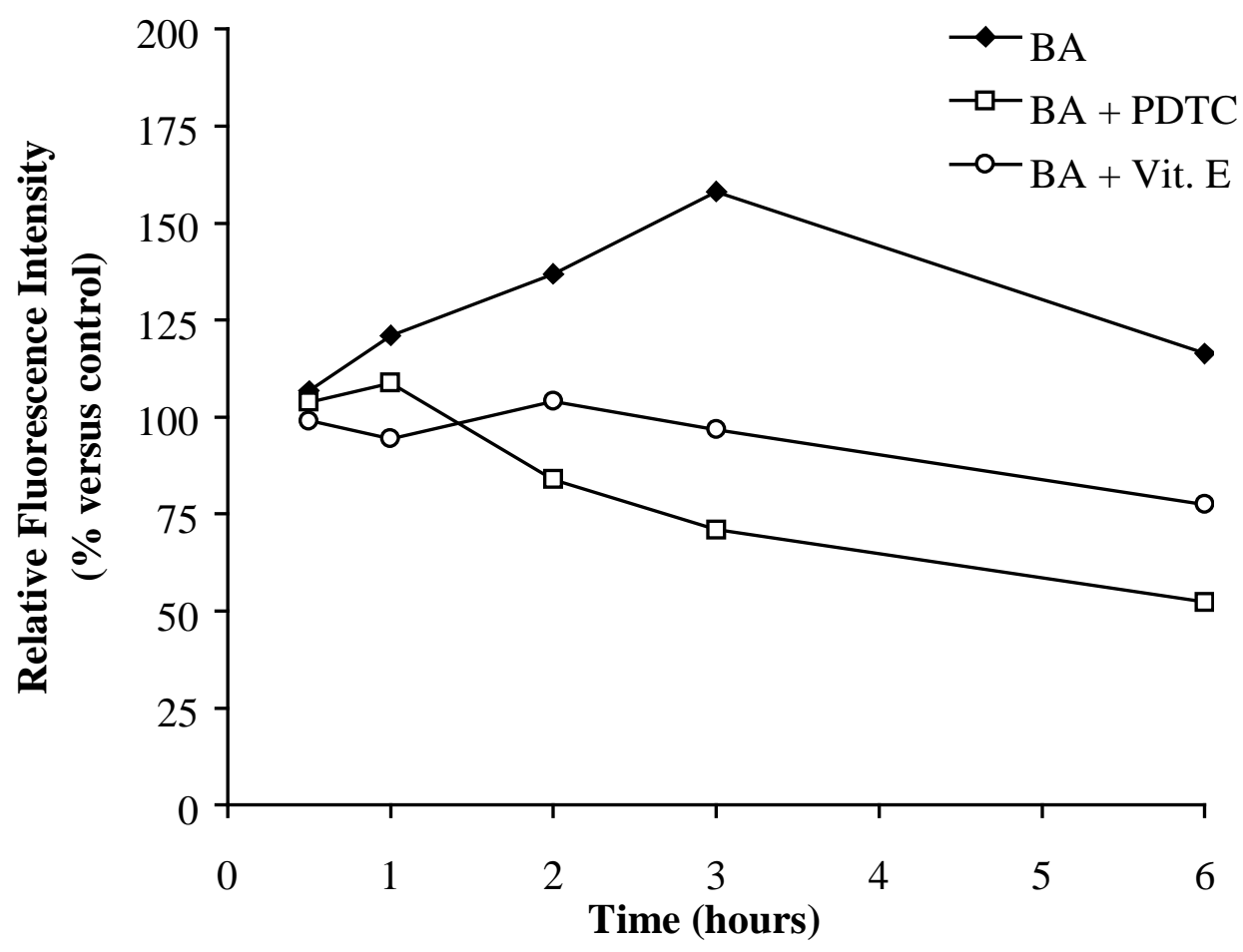




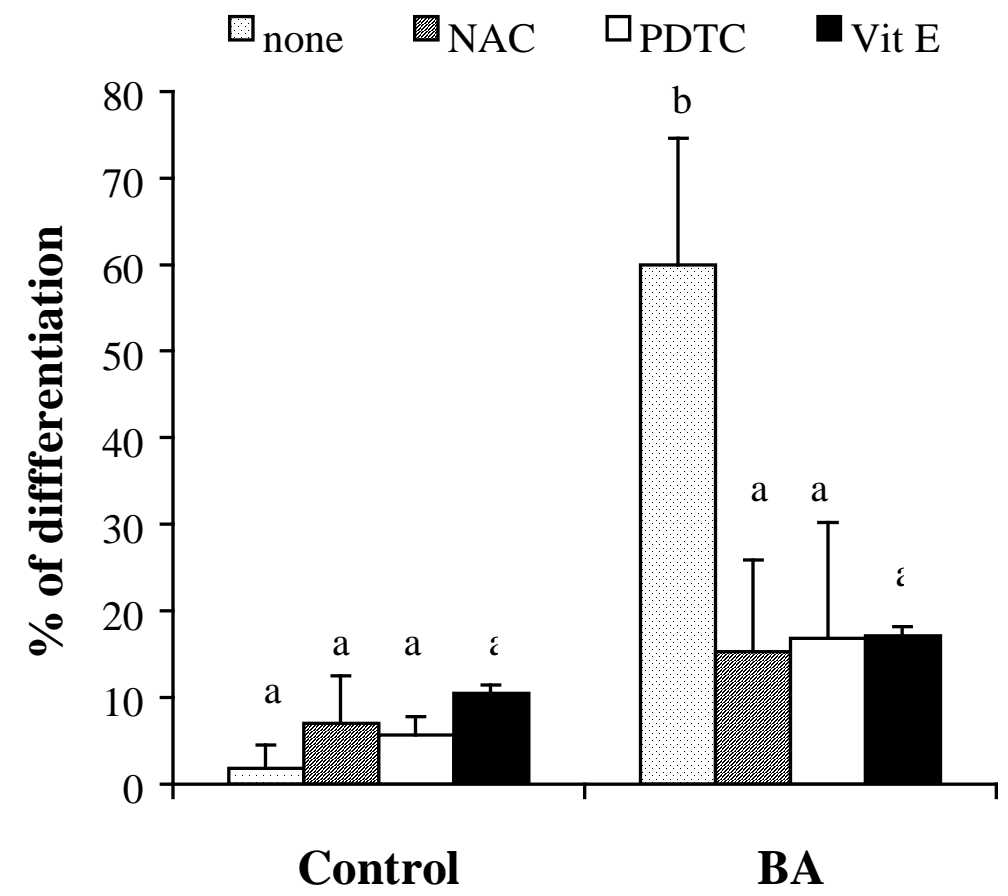


A

\begin{tabular}{ccccc}
\hline \multicolumn{3}{c}{ Control } & \multicolumn{3}{l}{ BA } \\
\hline$-\quad$ NAC & PDTC & - & NAC & PDTC \\
\hline & & & & \\
& & & &
\end{tabular}

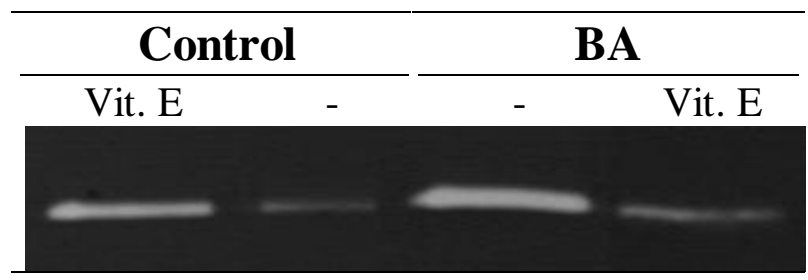

B

\begin{tabular}{ll}
\hline \multicolumn{2}{c}{ Control } \\
PDTC NAC - & - NAC \\
\hline
\end{tabular}

MMP-9

$\leftarrow 208$ pb

TIMP-1

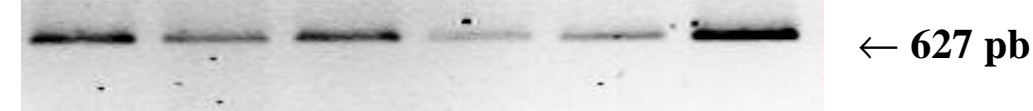

TIMP-2 $\leftarrow 364 \mathrm{pb}$

GAPDH

$\leftarrow 234 \mathrm{pb}$ 
A

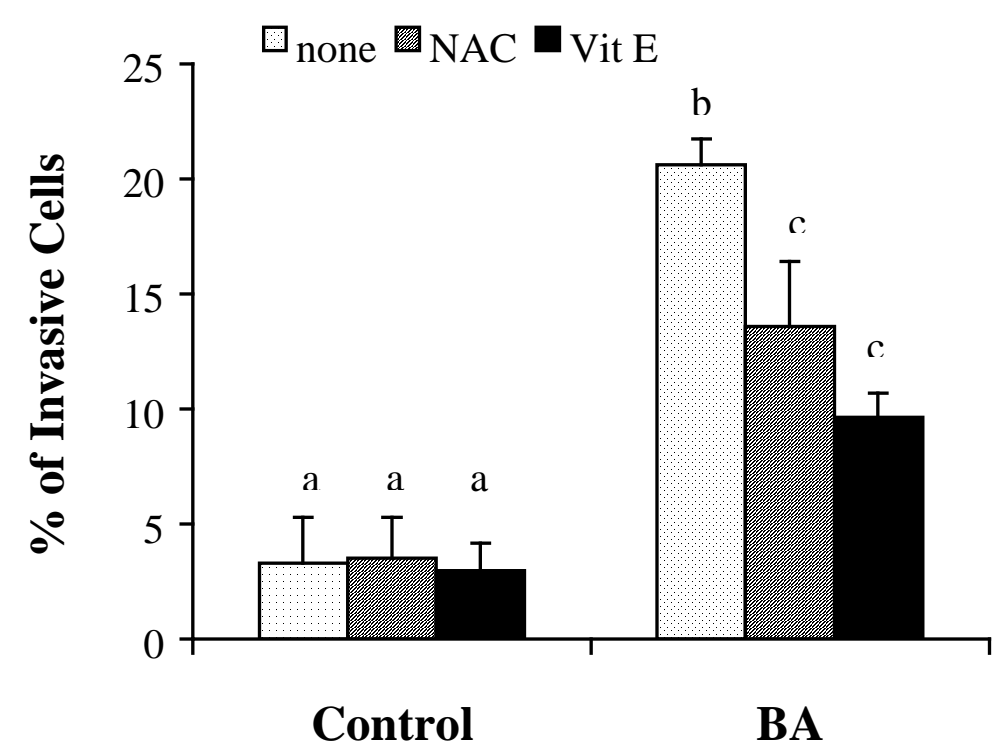

B

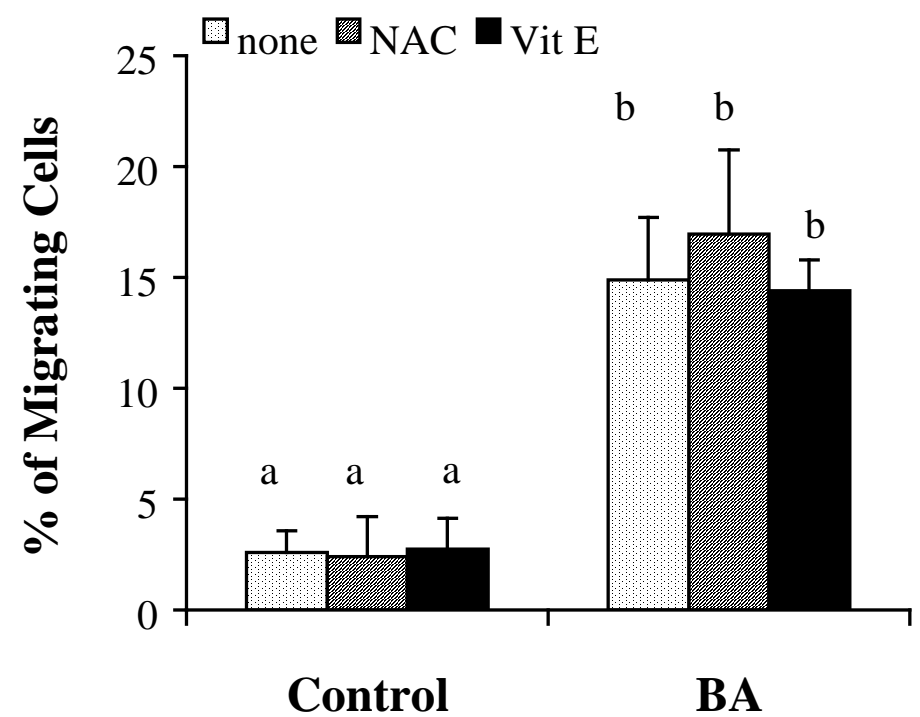

